\title{
On the Wegener granulomatosis associated region on chromosome 6p21.3
}

\author{
Paweł Szyld ${ }^{\dagger 1}$, Peter Jagiello ${ }^{\dagger 1,2}$, Elena Csernok ${ }^{3}$, Wolfgang L Gross ${ }^{3}$ and \\ Joerg T Epplen*1
}

Address: ${ }^{1}$ Human Genetics, Ruhr-University, Bochum, Germany, ${ }^{2}$ Clinical Molecular Biology, Christian-Albrechts-University Kiel, Germany and ${ }^{3}$ Rheumatology, University Hospital Luebeck and Rheumaklinik Bad Bramstedt, Germany

Email: Paweł Szyld - szyld@list.pl; Peter Jagiello - pjag@gmx.de; Elena Csernok - csernok@rheuma-zentrum.de; Wolfgang L Gross - gross@rheuma-zentrum.de; Joerg T Epplen* - joerg.t.epplen@rub.de

* Corresponding author †Equal contributors

Published: 09 March 2006

BMC Medical Genetics2006, 7:21 doi:10.1 186/147|-2350-7-21
Received: 29 July 2005

Accepted: 09 March 2006

This article is available from: http://www.biomedcentral.com/147I-2350/7/2I

(c) 2006Szyld et al; licensee BioMed Central Ltd.

This is an Open Access article distributed under the terms of the Creative Commons Attribution License (http://creativecommons.org/licenses/by/2.0), which permits unrestricted use, distribution, and reproduction in any medium, provided the original work is properly cited.

\begin{abstract}
Background: Wegener granulomatosis (WG) belongs to the heterogeneous group of systemic vasculitides. The multifactorial pathophysiology of WG is supposedly caused by yet unknown environmental influence(s) on the basis of genetic predisposition. The presence of anti-neutrophil cytoplasmic antibodies (ANCA) in the plasma of patients and genetic involvement of the human leukocyte antigen system reflect an autoimmune background of the disease. Strong associations were revealed with WG by markers located in the major histocompatibility complex class II (MHC II) region in the vicinity of human leukocyte antigen (HLA)-DPBI and the retinoid X receptor $B(R X R B)$ loci. In order to define the involvement of the 6p2I.3 region in WG in more detail this previous population-based association study was expanded here to the respective 3.6 megabase encompassing this region on chromosome 6. The RXRB gene was analysed as well as a splice-site variation of the butyrophilin-like (BTNL2) gene which is also located within the respective region. The latter polymorphism has been evaluated here as it appears as a HLA independent susceptibility factor in another granulomatous disorder, sarcoidosis.
\end{abstract}

Methods: 150-180 German WG patients and a corresponding cohort of healthy controls $(n=100-261)$ were used in a twostep study. A panel of 94 microsatellites was designed for the initial step using a DNA pooling approach. Markers with significantly differing allele frequencies between patient and control pools were individually genotyped. The RXRB gene was analysed for single strand conformation polymorphisms (SSCP) and restriction fragment length polymorphisms (RFLP). The splice-site polymorphism in the BTNL2 gene was also investigated by RFLP analysis.

Results: A previously investigated microsatellite (\#I.0.3.7, Santa Cruz genome browser (UCSC) May 2004 Freeze localisation: chr6:3 I 257596-34999883), which was used as a positive control, remained associated throughout the whole two-step approach. Yet, no additional evidence for association of other microsatellite markers was found in the entire investigated region. Analysis of the $R X R B$ gene located in the WG associated region revealed associations of two variations ( $\mathrm{rs} 10548957 \mathrm{P}_{\text {allelic }}=0.02$ and rs653I $\mathrm{P}_{\text {allelic }}=5.20 \times 10^{-5}, \mathrm{OR}=1.88$ ). Several alleles of markers located between HLA-DPBI, SNP rs653I and microsatellite 1.0.3.7 showed linkage disequilibrium with $r^{2}$ values exceeding 0.10 . Significant differences were not demonstrable for the sarcoidosis associated splice-site variation ( $r$ s2076530 Pallelic $=0.80$ ) in our WG cohort.

Conclusion: Since a microsatellite flanking the RXRB gene and two intragenic polymorphisms are associated significantly with WG on chromosome 6p21.3, further investigations should be focussed on extensive fine-mapping in this region by densely mapping with additional markers such as SNPs. This strategy may reveal even deeper insights into the genetic contributions of the respective region for the pathogenesis of WG. 


\section{Background}

Wegener granulomatosis (WG) is a granulomatous disorder belonging to the heterogeneous group of systemic vasculitides (SV). A common feature of $\mathrm{SV}$ is the inflammation of the endothelium $[1,2]$. SV are classified according to the size of affected vessels and the type of auto-antibodies, namely anti-neutrophil cytoplasmic antibodies (ANCAs), which are used for differential diagnosis $[3,4]$.

WG has an annual incidence of 5-10/million individuals in Caucasians [5]. The pathophysiology of WG still remains largely unknown with a supposedly multifactorial basis [6,7]. Presence of ANCA in the plasma of $~ 90 \%$ of WG patients reflects autoimmune background of the disease. In WG patients ANCAs are mostly directed against proteinase 3 (PRTN3), presented in primary azurophil granules of polymorph nuclear neutrophils (PMN) and lysosomes of monocytes [8,9]. After cytokine priming of PMN, PRTN3 translocates to the cell surface where ANCAs can bind and activate PMN resulting in a respiratory burst and release of proteolytic enzymes [10]. This may then lead to a self sustaining inflammatory process.

Several candidate genes such as PRTN3, $\alpha 1$-antitrypsine, adhesion molecule CD18 or interleukin 1 and its receptor have been investigated for WG association [11-15]. In addition, there is genetic evidence that the human leukocyte antigen (HLA) system is involved in WG development [16-19]. Yet, mostly these studies showed exclusively spurious WG associations. Recently, an extended association screen (EAS) revealed strong WG association of a microsatellite marker (UCSC May 2004 Freeze chr6:31257596-34999883) located in major histocompatibility complex class II (MHCII) region in the immediate vicinity of the HLA-DPB1 and retinoid $X$ receptor $\beta(R X R B)$ genes in two German populations [20]. Genotyping 19 alleles of the HLA-DPB1 gene with increased frequency of the $H L A-D P B 1{ }^{*} 0401$ allele supported the evidence that this region harbours at least one genetic factor for WG. But further association mapping encompassing a region of $\sim 280 \mathrm{~kb}$ with additional microsatellite and SNP markers did not allow to decide between several alternatives. Either this region harbours one major locus for WG, encompasses two susceptibility loci or the association of specific marker alleles is due to linkage with a causative locus at some distance. In this context, the complex linkage disequilibrium (LD) patterns are crucial with areas of densely packed recombination hot spots as well as large LD blocks on chromosome 6p thus further complicating to define associations in this region $[21,22]$. In a recent study on the granulomatous disorder sarcoidosis, a fine mapping approach using SNPs led to the definition of an HLA independent genetic factor, BTNL2 [23]. This study underlines the necessity of investigations on larger regions encompassing defined associations in order to evaluate aforementioned considerations on extended LD on chromosome 6, i.e. how far an association can extend, or HLA independent risk factors. Here, we expanded association mapping to a $3.6 \mathrm{mb}$ region encompassing the WG associated 6p21.3 as well as adjacent regions with additional microsatellites. This study was carried out in a two-step population based design using pooled DNA for the initial scan and, subsequently individual genotyping of markers that differed statistically significantly between WG patients and controls.

Furthermore, we focussed on two candidate genes on chromosome 6, RXRB and butyrophilin-like 2 (BTNL2) located in the vicinity or even in the respective WG-associated region [20]. $R X R B$ presents as a good candidate as the protein binds to hormone nuclear receptors such as the vitamin D receptor (VDR) [24]. VDR and its ligand calcitriol have widespread influence on immuno-regulatory systems [25-28]. Thereby, RXRB variation may be involved in the pathogenesis of WG. In order to find functionally relevant polymorphisms the entire coding region and $~ 593$ bp of the promoter were screened for variations. Furthermore, a recently described splice-site polymorphism of the BTNL2 gene has been reported to represent a HLA independent risk factor for another granulomatous disorder affecting the lung, namely sarcoidosis [23]. $B T N L 2$ is located on $6 \mathrm{p} 21.3$ in the vicinity of the HLADRB1 locus. On the basis of sharing traits in WG and sarcoidosis such as granulomas and pulmonary affections, the functionally relevant splice-site polymorphism was genotyped in our cohorts.

\section{Methods \\ Patients}

German WG patients were clinically diagnosed according to international standards by applying the 1990 classification criteria of the American College of Rheumatology [29] and the definitions of the 1994 Chapel Hill Consensus Conference [3]. All patients have defined ANCA-status $\left(\mathrm{n}_{\text {positive }}=151 ; \mathrm{n}_{\text {negative }}=30\right)$. WG was biopsy-proven in the German reference centre for vasculitis (Department of Pathology, University of Schleswig-Holstein Campus Luebeck, Germany) by 2 different observers. Control groups comprised healthy adults from northern Germany and the Ruhr area (Germany). The institutional Ethics Committee of Bochum Ruhr-University approved this study. Informed consent was obtained from all individuals.

\section{Pooling of DNA}

DNA pooling was performed as described before [20]. Briefly, DNA concentrations were measured spectrophotometrically in 4 steps, and samples were diluted accordingly. The final DNA concentration in pools was $50 \mathrm{ng} / \mu \mathrm{l}$. In order to control for artefacts during pooling, 150 
Table I: Oligonucleotides and restriction enzymes used for SSCP analyses of the exonic and 593 bp promoter regions of the RXRB gene.

\begin{tabular}{|c|c|c|c|}
\hline Exon & Oligonucleotide sense/antisense & PCR product (bp) & $\begin{array}{l}\text { Restriction enzyme; } \\
\text { length of fragments } \\
\text { (bp) }\end{array}$ \\
\hline $0 \mathbf{l a}$ & CGGTATCCCTACTCTCAGCCA/GCGGGATCCAGCCAGG & 164 & - \\
\hline Olb & GGTGCGAAAAGAAATGCA/CACTGGCTCGCCTGCC & 202 & - \\
\hline 02 & $\begin{array}{l}\text { CTCTTGTGTGTCTGTGTGCCT/ } \\
\text { GGTTAGAGGATTGGAAGGTCA }\end{array}$ & 403 & Avall $176 / 227$ \\
\hline 03 & GACTTCCCTATTTCCCCCAT/TCTCGGAGAAGAGGAGGCT & 207 & - \\
\hline 04 & TGAAGGTGTCTCCATGCAAC/AGAAGGGCATGTGGTCTAAGA & 275 & BsmFI I26/I49 \\
\hline 05 & CTGATGAGGCCGTAAGGATA/GTGGATTGACCCCAACACT & 280 & Eco24I $130 / 150$ \\
\hline 06 & TCCATAACTCTTACCCCCGT/CTGGGTACGCAAGGTAAGG & 255 & Mboll 102/I53 \\
\hline 07 & CCTGATTTCTGGCTCCTGAC/CCTCTATCTACATGCCAGCCT & 209 & - \\
\hline 08 & GCTGAGCTGTGACCTTTGAGT/TCTCGGAGAAGAGGAGGCT & 199 & - \\
\hline 09 & СТССТСТСТTСССТGССАT/ССТСАTAGСАСТССССАСС & 199 & - \\
\hline 10 & СТСАATССССТTСТСССАC/AGTGTGAGAAGCACCACGTC & 209 & - \\
\hline \multicolumn{4}{|c|}{ Promoter (593 bp) } \\
\hline Sys I & GGGCTTAATTCGACCCAA/GCATTTCTTTTCGCACC & 213 & - \\
\hline Sys2 & GCTAACAGGCCGGAGGAGA/GGATTGATCGGAGGATTAGCT & 212 & - \\
\hline Sys3 & СTCTCCTTTCCCGGTTTG/TCGTCTAGTTGGAAACCGAG & 234 & - \\
\hline Sys 4 & СТСTTTATCCCGAACCACCT/TCTCGCGGGATCTAAAGG & 221 & - \\
\hline Sys5 & CATCACGCTGACCAGAGG/TGGTGAAAGATTAGTGTCCCA & 214 & - \\
\hline
\end{tabular}

ANCA-positive patients were divided into 3 sub-pools and 100 controls from the northern German cohort into 2 sub-pools, respectively.

\section{Microsatellite marker panel}

A panel of 94 markers was designed encompassing the WG associated 6p21.32 and flanking regions (annotated by Santa Cruz genome browser (UCSC): chro6:31255920-34938760, May 2004 freeze, see [30]). Microsatellites were chosen utilizing the simple-repeat option of UCSC. The average distance between microsatellite markers was $41 \mathrm{~kb}$ (standard deviation 30 kb) with five gaps of distances $\geq 100 \mathrm{~kb}(<152 \mathrm{~kb})$. Most of the microsatellites harboured dinucleotide repeats $(68 \%)$, the remaining comprised tri-, tetra- or penta-nucleotide repeat motifs. Further information about the microsatellites is available as additional file 1 (website: [31]). No marker revealed significantly differing 'intra sub-pool' distributions as reflected by the p value (see below).

\section{PCR}

For fragment analysis we used fluorescence 5'FAM labelled, tailed oligonucleotide added to the 5'-part of the sequence specific primer as described before [20]. Primers were designed with the Primer Express 2.0 Software (Applied Biosystems, Foster City, USA). Melting temperature was set to $55^{\circ} \mathrm{C}$. Three primers were used for PCR: tailed forward primer (tailed $\mathrm{F}$ ), reverse primer and labelled primer (labelled F) corresponding to the 5'-tail sequence of tailed F. Reaction mix consisted of $1 \times$ PCR buffer (Qiagen GmbH, Hilden, Germany), 1.5 pmol labeled F, $0.2 \mathrm{mM}$ each dNTP, $3 \mathrm{mM} \mathrm{MgCl}_{2}, 0.2 \mathrm{pmol}$ tailed F, 1.5 pmol reverse primer, 0.25 U Qiagen Hot Start Taq (Qiagen) and $50 \mathrm{ng}$ DNA. PCR was performed in a Biometra T-Gradient Thermoblock (Biometra, Göttingen, Germany) using the following characteristics: activation step at $95^{\circ} \mathrm{C}$ for $15 \mathrm{~min} ; 35$ cycles of denaturation at $95^{\circ} \mathrm{C}$ for $1 \mathrm{~min}$, annealing at $55^{\circ} \mathrm{C}$ for $1 \mathrm{~min}$ and extension at $72^{\circ} \mathrm{C}$ for $1 \mathrm{~min}$; and a final extension at $72^{\circ} \mathrm{C}$ for $10 \mathrm{~min}$.

\section{Initial screen}

Electrophoresis and data analysis were performed on a 48well ABI377 slab-gel system using ABI Genotyper software as described before [20]. Data analysis generated markerspecific allele image profiles (AIPs) representing distributions of alleles within each sub-pool.

\section{Statistical analysis}

AIPs of WG pools were compared with those of the control cohort. Peak heights were cumulated to 100\% (representing 100 alleles in each pool, respectively). Afterwards allele frequencies (corresponding to peaks height) were calculated according to the estimated total allele count. Association was tested for each marker by comparison of the AIPs from WG-DNA pools with those of controls by contingency tables using a significance level of $p=0.05$. In order to focus the statistics on major effects, alleles with a frequency of less than $5 \%$ were summarized to one allele. Next, frequency distributions were compared by means of contingency tables as mentioned above. The resulting $\mathrm{p}$ values were corrected for multiple testing using QValue software [32,33] with a 'cut off of 5\%. Nevertheless, noncorrected p values were simply ranked according to their evidence for association in order to select markers for fur- 
ther studies. In addition, intra-population differences were tested by comparing WG pools with each other as well as both control pools.

\section{Individual genotyping}

In order to exclude false positive significances, patients and controls were individually genotyped for respective markers. Genotyping was performed on the Beckman Coulter CEQ8000 8-capillary system using 'Fragment Analysis Module' software (Beckman Coulter, Inc., Fullerton, USA). Reaction mix contained $1 \times$ PCR buffer (Qiagen), 0.75 pmol fluorescent labelled $F, 0.2 \mathrm{mM}$ each dNTP, $3 \mathrm{mM} \mathrm{MgCl}_{2}, 0.2$ pmol tailed F, 1.5 pmol reverse primer, 0.25 U Qiagen Hot Start Taq (Qiagen) and 50 ng DNA. Parameters for amplification were used as described above. Allele and genotype frequency of WG patients and controls were compared by $\chi^{2}$-testing. Additionally, Hardy-Weinberg equilibrium was tested using Genepop software [20].

\section{Screening of the coding and a 593 bp promoter region in the RXRB gene}

The coding and promoter regions (593 bp) of the RXRB gene were initially screened by single strand conformation polymorphism (SSCP) with 48 patient (ANCA-positive) and 48 control DNAs. The RXRB sequence was downloaded from UCSC database (NM021976, July 2003 Freeze). Oligonucleotides were designed using Primer Express 2.0 Software (Applied Biosystems) with an optimal annealing temperature of $57^{\circ} \mathrm{C}$ (see table 1). PCR was performed using Qiagen HotStar Taq (Qiagen) with an initial denaturation at $95^{\circ} \mathrm{C}$ for $15 \mathrm{~min}, 35$ cycles of $94^{\circ} \mathrm{C}$ for $30 \mathrm{sec}-57^{\circ} \mathrm{C}$ for $30 \mathrm{sec}-72^{\circ} \mathrm{C}$ for $30 \mathrm{sec}$ and a final extension at $72^{\circ} \mathrm{C}$ for $10 \mathrm{~min}$. PCR conditions were chosen as recommended by Qiagen. Fragments were labelled with $\alpha$-dATP (exons 2-10; Hartmann Bioanalytics, Braunschweig, Germany) and $\alpha$-dCTP (exon $1 \mathrm{a}$ and $1 \mathrm{~b}$; Hartmann Bioanalytics). SSCP were analysed on $6 \%$ and $5 \%$ polyacrylamide gels with either $5 \%$ or $10 \%$ glycerol. The gels were run at room temperature at $35 \mathrm{~W}$. Amplificates containing obvious band shifts were sequenced using dye terminator cycle sequencing on an ABI377 automatic sequencer (Applied Biosystems). Statistical comparisons of allele frequencies and genotypes were based on the $\chi^{2}$ test. In addition, Hardy-Weinberg equilibrium has been tested for all SNPs.

\section{Genotyping of rs6531}

The sequence variation rs6531 was genotyped in 151 ANCA-positive patients and 201 controls by RFLP analysis. A restriction site for DdeI (NewEnglandBiolabs, Ipswich, USA) was generated by using the tailed mismatch oligonucleotide, mmantisense-CATCGCTGATTCGCACATCATCAATGGATCGGTCTGA. PCR was performed by 'the tailed primer' method using three oligonulceotides: the mmantisene-primer, an oligonucleotide corresponding to the tail and the forward oligonucleotide senseCCGATCTTTAGTGACCCCAGT. Restriction with DdeI results in a $226 \mathrm{bp}$ fragment (T allele) and in case of the $\mathrm{C}$ allele in 2 fragments of 192 and 34 bp, respectively. Electrophoresis was done on a 3\% agarose gel containing ethidium bromide. The results were analysed with the $\chi^{2}$ test and Hardy-Weinberg equilibrium was controlled.

\section{Genotyping of the Val95Ala polymorphism in the RXRB gene}

The previously reported the Val95Ala polymorphism [34] was genotyped by RFLP analysis in 94 patients and 90 controls. Fragments were amplified using oligonucleotides Val95Ala sense-CGGTGGGGTATTAGAGAATT and Val95Ala antisense-CCCATGGAAGAACTGATGACTGG. PCR was performed with Qiagen HotStar Taq (Qiagen) as described above with an annealing temperature of 55$60^{\circ} \mathrm{C}$ and different $\mathrm{MgCl}_{2}$-concentrations generating a 300bp fragment. The 2 alleles (Val, T allele; Ala, C allele) are detected as $232 \mathrm{bp}$ and $193 \mathrm{bp}$ bands, respectively.

Electrophoresis was done in ethidium bromide containing 2\% agarose gels. In order to control the results of the RFLP analysis, DNAs of 15 patients and 20 controls were sequenced as described above. Association was verified with the $\chi^{2}$ test and Hardy-Weinberg equilibrium.

\section{Genotyping the functionally relevant BTNL2 variation rs2076530}

Primer extension analysis was used to genotype the truncating splice site mutation in 180 patients and 261 controls. Two primers were designed for amplification, forward TCCAGATACTCAGTGCCAGA, reverse: TTGTCCAGGAACTAGCATATT. PCR conditions were: $1 \times$ PCR buffer (Qiagen), $0.2 \mathrm{mM}$ each dNTP, $0.2 \mathrm{pmol}$ forward primer, $0.2 \mathrm{pmol}$ reverse primer, 0.25 U Qiagen Hot Start Taq (Qiagen) and $50 \mathrm{ng}$ DNA. The reaction was performed with initial denaturation at $95^{\circ} \mathrm{C}$ for $15 \mathrm{~min}, 35$ cycles of $94^{\circ} \mathrm{C}$ for $30 \mathrm{sec}-60^{\circ} \mathrm{C}$ for $30 \mathrm{sec}-72^{\circ} \mathrm{C}$ for $30 \mathrm{sec}$ and a final extension at $72^{\circ} \mathrm{C}$ for $10 \mathrm{~min}$ The product was purified with magnetic beads system (AMPure; ABgene, Epsom, UK). A primer extension reaction was performed with the interrogation primer: GCCCAGTTTGGATCTGAAGGTGGTA using Beckmann $\mathrm{CEQ}^{\mathrm{TM}}$ SNP-Primer Extension Kit (Beckman Coulter) under recommended conditions. Electrophoresis and data analysis was performed using Beckman Coulter CEQ8000. Statistical analysis was based on the $\chi^{2}$ tests, and allele frequencies were tested for Hardy-Weinberg equilibrium.

\section{LD analyses}

We calculated pair-wise LD between HLA-DPB1 alleles (genotypes obtained from a previous study [20], see additional file 2, website: [35]), rs6531 and the significantly 
Table 2: $\mathbf{P}$ values for microsatellite markers after the initial step and individual genotyping.

\begin{tabular}{|c|c|c|c|}
\hline \multirow[b]{2}{*}{ Code of marker } & \multirow[b]{2}{*}{ Number of alleles } & \multicolumn{2}{|c|}{ p values } \\
\hline & & $\begin{array}{c}\text { after analysis with pooled } \\
\text { DNA }\end{array}$ & $\begin{array}{c}\text { after summation of rare } \\
\text { alleles }(<5 \%)\end{array}$ \\
\hline \#I.0.0.1 & 5 & 0.02 & 0.01 \\
\hline \#I.0.0.5 & 12 & 0.03 & 0.01 \\
\hline$\# 1.0 .3 .4$ & 3 & 0.04 & 0.05 \\
\hline$\# 1.0 .3 .7^{*}$ & 5 & $2 \times 10^{-4}$ & $3 \times 10^{-4}$ \\
\hline \multirow[t]{2}{*}{$\# 1.0 .4 .1$} & 6 & $1 \times 10^{-4}$ & $4 \times 10^{-4}$ \\
\hline & \multicolumn{3}{|c|}{ p values } \\
\hline Code of marker & $\begin{array}{l}\text { after analyses of each single } \\
\text { allele (most significant allele) }\end{array}$ & $\begin{array}{c}\text { after individual genotyping ( } p_{c} \\
\text { value) }\end{array}$ & after correction by $Q$-value \\
\hline \#I.0.0.1 & 0.03 & n.s. & n.s. \\
\hline \#I.0.0.5 & $>0.05$ & n.s. & n.s. \\
\hline \#I.0.3.4 & 0.03 & n.d. & n.d. \\
\hline$\# 1.0 .3 .7^{*}$ & $<1 \times 10^{-4}$ & $4 \times 10^{-5}\left(P_{c}=3 \times 10^{-4} ; c=5\right)$ & n.s. \\
\hline \#1.0.4.1 & $3 \times 10^{-3}$ & n.s. & n.s. \\
\hline
\end{tabular}

n.s. = not significant; n.d. $=$ not determined; $*=$ positive control

associated microsatellite \#1.0.3.7 in our control and patient cohorts. Microsatellite, SNP and HLA-DPB1 alleles with frequencies below 0.05 were excluded. For pairwise LD calculation we presumed each microsatellite allele to be biallelic, i.e. one distinct allele against all others pooled. The same procedure was applied for the most frequent HLA-DPB1 alleles ${ }^{*} 0401,{ }^{*} 0402,{ }^{*} 0201$ and *0301. The strength of LD between all three markers was quantified by $\mathrm{D}^{\prime}$ and $\mathrm{r}^{2}$ values. LD analyses were calculated by Haploview 3.2 [36].

\section{Results}

\section{Initial association mapping}

Eighty four markers were analysed in an initial scan (after exclusion of non-polymorphic and recurrently artefactproducing microsatellites). Thereof, five microsatellites revealed significant differences in allele distribution between WG patients and controls (see table 2). Correction for multiple comparisons with QValue rejected significance for all results. Nonetheless, markers were simply ranked according to their $\mathrm{p}$ values. Thereafter, four markers were selected for individual genotyping (see figure 1). One microsatellite showed only marginal significance (\#1.0.3.4) after summation of rare alleles $(<5 \%)$ and thus was excluded from further investigations. Individual genotyping confirmed exclusively one marker (adjacent to $R X R B)$, the positive control, as statistically significantly different: \#1.0.3.7 ( $\mathrm{p}=3 \times 10^{-4}$, see table 2$)$.

\section{Analyses of the RXRB gene}

SSCP analyses in the RXRB gene did not reveal any variations in exons $1-5,8-10$ and the 593 bp promoter region. Similarly, the Val95Ala polymorphism was neither detectable by RFLP nor by sequence analyses in our patient and control cohorts. Yet, the analysis of the PCR product comprising exon 6 revealed a band shift. Subsequent sequencing showed an intronic CT-INDEL polymorphism which has been reported before (rs10548957). Statistical analysis of the allele frequencies revealed a p value of 0.02 with a minor allele frequency of 0.07 in the control cohort ( $\mathrm{n}$ $=47)$ and total absence in the patients $(\mathrm{n}=43)$. In exon 7 a single nucleotide polymorphism (SNP) (rs6531) was detected using SSCP and sequencing. Comparison of allele frequencies of patients $(\mathrm{n}=151) v s$. controls $(\mathrm{n}=$ 201) revealed significant $p$ values (see table 3 for detailed analyses). Additionally 28 ANCA-negative patients were genotyped for this SNP and compared to either the ANCApositive patients or the control cohort. There is a significant deviation between the ANCA-negative and -positive patients regarding this SNP. The ANCA-negative cohort did not differ from the control group.

\section{LD analyses}

Several alleles between HLA-DPB1, rs6531 and microsatellite marker \#1.0.3.7 showed LD with $r^{2}$ values exceeding 0.10 (for detailed description see figure $2 \mathrm{~A}$ and $2 \mathrm{~B}$ ). For example, strong LD exists between HLA-DPB ${ }^{*} 0401$ and microsatellite allele $* 3$ as well as the rs6531 polymorphism in the patient and control cohorts. 


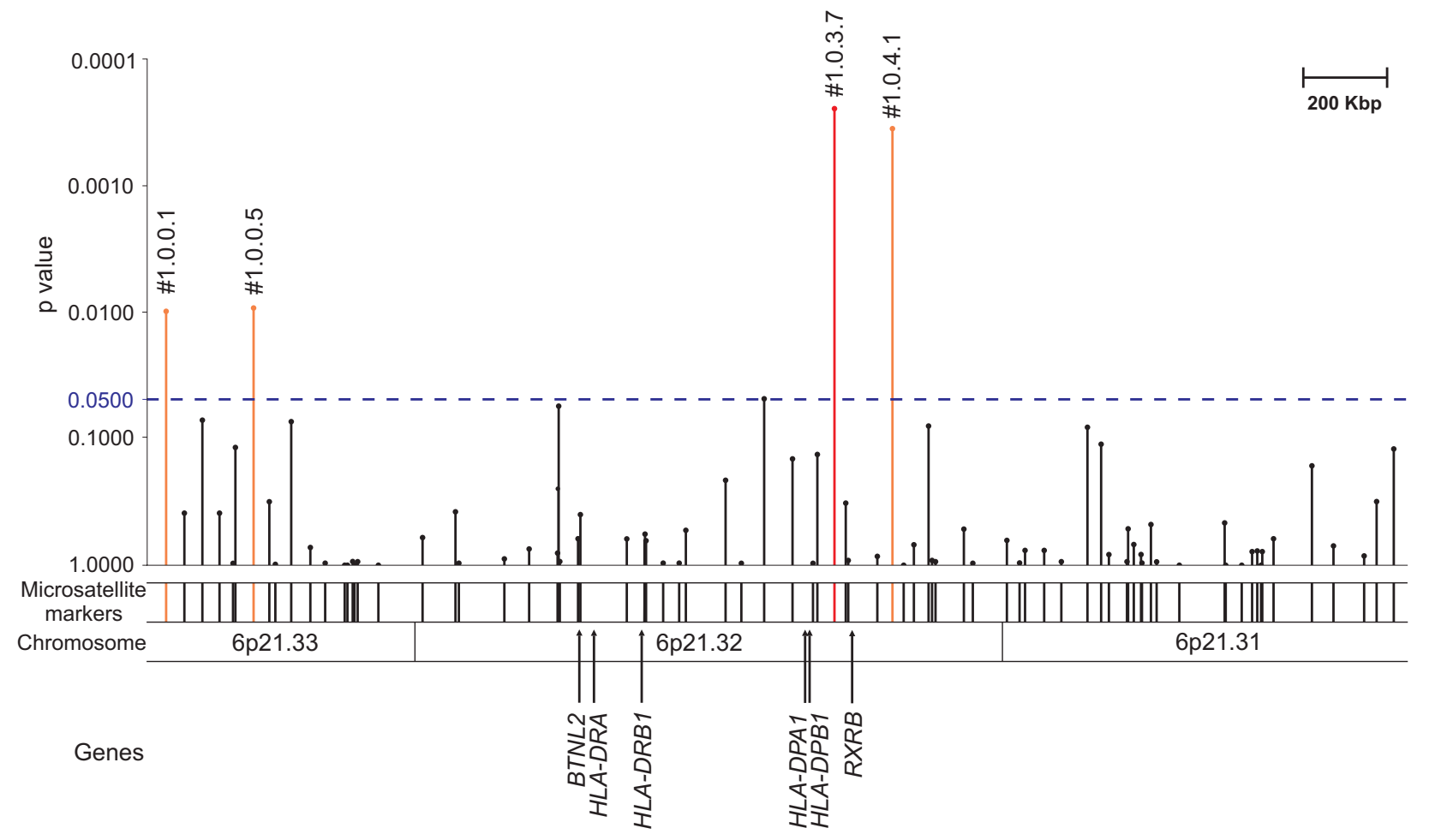

\section{Figure I}

Map of the investigated HLA region with $\mathrm{p}$ values of the markers used in the initial screen. Figure shows the investigated fragment of chromosome 6 comprising the previously defined WG associated region encompassing the HLA-DPBI and $R X R B$ genes. Vertical lines represent studied microsatellites. The lengths/heights of these lines correspond to $p$ values after analyses in the initial screen with pooled DNA. The 4 markers, which were genotyped individually, are labelled. The $p$ values of markers \#I.0.0.1, \#I.0.0.5 and \#I.0.4.I (pool analysis) could not be replicated by genotyping individually. Drawn in red is the marker (\#I.0.3.7) that remained significantly different after individual genotyping. This marker has been used as a positive control (see text). For further information of fine localisation of each investigated marker and inter-marker distances see additional file I.

\section{Analysis of the functionally relevant BTNL2 variation} Genotyping of rs2076530 polymorphism in 180 patients and 261 controls (Northern Germany and Ruhr area populations) did not reveal any statistically significant difference in allele, phenotype and genotype frequencies between all WG patients and healthy individuals (see table 4). In addition, when dividing the patient cohort into $\mathrm{ANCA}^{+}$and ANCA-patients, significant differences were not detected between the respective patient and control cohorts (data not shown).

\section{Discussion}

The approach using pooled DNA and allele image profiles for microsatellite based association studies was used to investigate groups of candidate genes for different multifactorial disorders revealing novel predisposition factors for respective diseases [20,37]. For these studies markers were chosen located intra- or juxtagenically to distinct genes. Here, we used a population based association study approach with microsatellites and DNA pooling for scanning a $3.6 \mathrm{mb}$ region on $6 \mathrm{p} 21.3$. This chromosomal segment includes the previously characterized, WG associated region [20]. Several other studies have revealed associations of HLA genes with WG and other vasculitides (e.g. $[17,19,38-41])$. Yet, most of these results could not be replicated. Considering the highly variable HLA complex, the strong positive selection effects on this region in combination with the relatively limited number of investigated patients, definitive conclusions are truly challenging. By using our EAS approach we searched for further loci for WG or whether the identified HLA-DPB1/RXRB associations are due to linkage with other factors located more distantly on 6p21.3 comprised in the genomic region investigated here. Yet, we could neither reveal any 
Table 3: Genotyping of rs653I in the RXRB gene.

\begin{tabular}{lccc}
\hline Genotypes/phenotypes/alleles & Patients ANCA $(\mathbf{n}=\mathbf{I 5 I})$ & Patients ANCA- $(\mathbf{n}=\mathbf{3 6})$ & Controls $(\mathbf{n}=\mathbf{2 0} \mathrm{I})$ \\
\hline CC & 36 & 15 & 92 \\
CT & 87 & 19 & 88 \\
TT & 28 & 2 & 21 \\
& & & 180 \\
CC+CT (vs. TT) & 123 & 34 & 109 \\
TT+CT (vs. CC) & 115 & 21 & 272 \\
C & 159 & 49 & 130
\end{tabular}

ANCA+ $^{+}$against ANCA- patients

$\mathrm{ANCA}^{+}$patients against controls

Genotypes/phenotypes/alleles

\begin{tabular}{|c|c|c|c|c|}
\hline & $P$ value & OR (95 \% C.I.) & $P$ value & OR (95 \% C.I.) \\
\hline CC & 0.03 & & $2.3 \times 10^{-5}$ & \\
\hline CT & 0.10 & $1.91(0.87 \text { to } 4.16)^{*}$ & $1.6 \times 10^{-4}$ & $2.53(1.55 \text { to } 4.1 \mathrm{I})^{*}$ \\
\hline TT & 0.02 & 5.83 (1.23 to 27.65$)^{*}$ & 0.03 & 5.89 (3.0I to II.53)* \\
\hline CC+CT (vs. TT) & 0.07 & $0.26(0.06$ to I.I4) & 0.03 & $0.5 \mathrm{I}(0.29$ to 0.94$)$ \\
\hline $\mathrm{TT}+\mathrm{CT}$ (vs. CC) & 0.03 & 2.26 ( 1.17 to 4.88$)$ & $2.3 \times 10^{-5}$ & 2.70 ( 1.69 to 4.30$)$ \\
\hline C & $1.0 \times 10^{-2}$ & & $5.2 \times 10^{-5}$ & \\
\hline $\mathbf{T}$ & & I.9I (I.II to 3.30) & & 1.88 (1.38 to 2.56$)$ \\
\hline
\end{tabular}

$\mathrm{OR}=$ odds ratio, $\mathrm{C} . \mathrm{I} .=$ confidence interval.

*Odds ratios for the CT and TT genotypes are contrasted against the CC genotype. No evidence for statistical difference between the ANCAnegative WG patients and the control cohort was revealed, when calculating all off above-used comparisons.

evidence for an additional locus nor for an expanded, significantly associated 'HLA-DPB1/RXRB' region, respectively. In our study, the only marker (\#1.0.3.7) which remained significantly associated has been reported before [20]. This marker is located in the immediate vicinity of the RXRB gene and $\sim 125 \mathrm{~kb}$ centromeric to HLA$D P B 1$. Hence we calculated LD of the microsatellite, HLADPB1 alleles (with data from a previous study [20]; see additional file 2 ) and the significantly differing, intragenic
rs6531RXRB SNP. These analyses e.g. confirmed results of Rajisbaum et al. [42] which revealed significant LD between polymorphisms in $R X R B$ and $H L A-D P B 1$. In order to definitively investigate this very locus, a more detailed approach with a dense map of additional markers (preferential SNPs) appears mandatory.

It remains possible, that loci of small effects escaped detection in our microsatellite-based association mapping

Table 4: Genotyping of rs2076530 in the BNTL2 gene.

\begin{tabular}{lccc}
\hline Genotypes/phenotypes/alleles & Patients ${ }^{* 1}(\mathbf{n}=\mathbf{~ I 8 0})$ & Controls $(\mathbf{n}=\mathbf{2 6} \mathbf{I})$ & P value \\
\hline GG & 68 & 79 & 0.27 \\
GA & 76 & 135 & 0.14 \\
AA & 36 & 47 & 0.94 \\
GG+GA & 144 & 214 & 0.84 \\
AA+GA & 112 & 182 & 0.19 \\
G & 212 & 293 & 0.80 \\
A & 148 & 229 &
\end{tabular}

\footnotetext{
${ }^{*}$ ANCA positive $(n=150)$ and ANCA negative $(n=30)$ patients. No statistically significant difference between the ANCA positive and negative patients was evident.
} 
2A

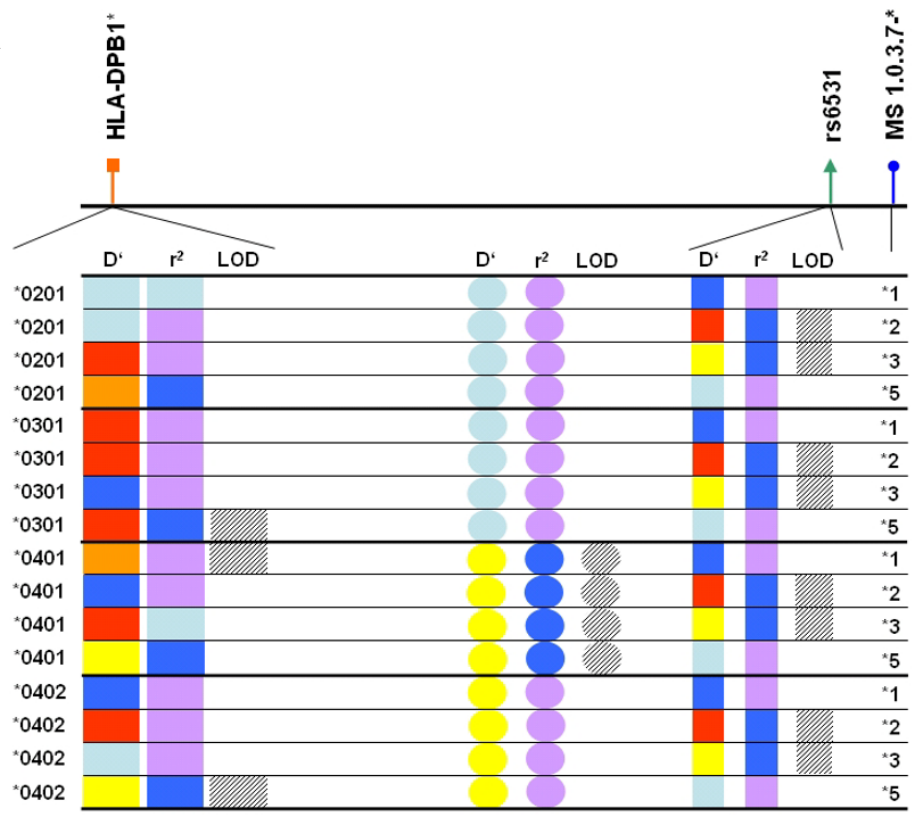

2B
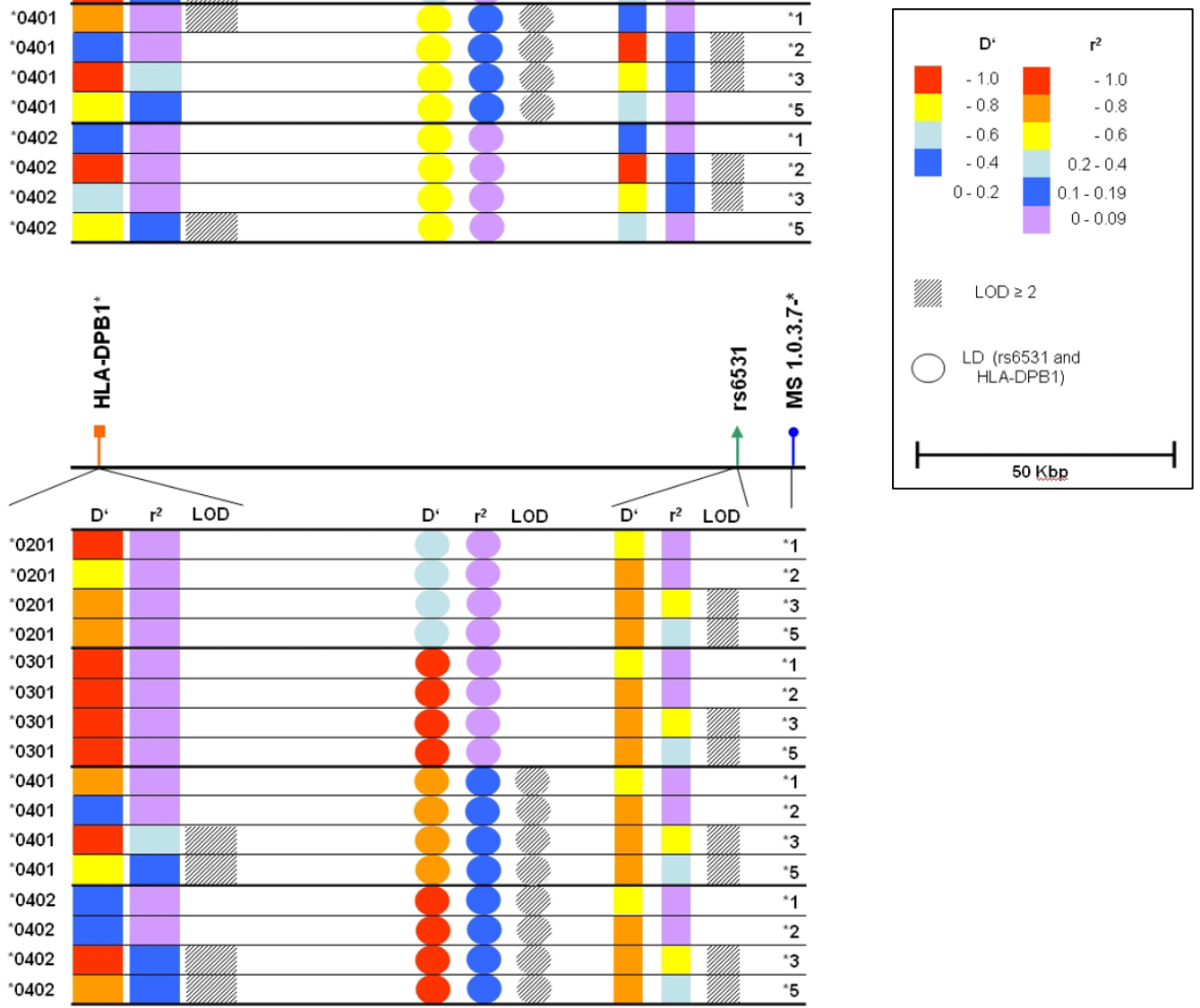

\section{Figure 2}

Graphical overview of LD analyses with frequent HLA-DPBI alleles, the rs653 I polymorphism in the RXRB gene and alleles of the significantly WG-associated \#I -0.3.7 microsatellite marker. Pair-wise LD evaluated by $D^{\prime}$ and $r^{2}$ between markers in the previously found WG associated chromosome 6 region for controls $(2 A)$ and patients (2B). Vertical lines with circle, triangle and square represent the relative localisation of each tested marker (HLA-DPBI, RXRB rs653I and microsatellite marker \#1.0.3.7, respectively). $D^{\prime}$ and $r^{2}$ values are indicated by colour coding. Logarithm of odds (LOD) values equal to or exceeding 2 are represented by dashed rectangles, circles or squares. Rectangles are related to LDs between the microsatellite \#I 0.3.7 and HLA-DPBI alleles. Circles represent LD values between HLA-DPBI and the SNP. Squares show LDs between the microsatellite alleles and rs653I SNP. The investigated alleles of the microsatellite markers are shown at the left hand side of the figure, whereas the different designations of the HLA-DPB/ alleles are depicted at the right hand side. MS: microsatellite. 
- a procedure known to ascertain strong associations. Such deficiency might be due to artefacts in the pooling procedure and analyses with pooled DNA such as lengthdependent amplification of short microsatellite marker alleles or even the presence of null-alleles. In addition, the slab-gel system approach might reflect a further hindrance in this subtle procedure, since it is not $100 \%$ consistent. Altogether such shortcomings could result in false allele frequencies thus ignoring truly positive low-effect loci, for which extremely precise data are necessary. A further explanation for the negative results for most markers is that our panel may not represent the whole region completely. Hence the possibility remains that we missed causative alleles due to lack of LD between a distinct marker allele and the respective susceptibility factor. More detailed information on haplotype block structures and future definition of LD between multiallelic microsatellite markers may facilitate even more far-fetched interpretations of our analyses. Nevertheless, our data indicate that the here investigated region might harbour only one (major) locus associated with WG as represented by the control marker in the vicinity of RXRB ( $\sim 5 \mathrm{~kb})$ showing a positive result. By applying QValue correction tests, the significance of this marker would have been rejected. Similar controversies were presented recently in a study for narcolepsy utilizing EAS using correction according to Bonferroni [37]. Hence, further analyses on this region were performed regardless of the correction for multiple comparisons.

In addition to the indirect association study with microsatellites, we screened the entire coding (including the splice-sites) and the promoter region of $R X R B$ in order to seek putative functionally relevant variations. In these analyses two polymorphisms were evident: an intronic CT-INDEL (rs10548957) variation revealing only a marginal association with WG, whereas the synonymous SNP (rs6531) in exon 7 was strongly associated (table 3). Nevertheless, this latter SNP does not affect known functional sequences influencing splicing and or regulation of gene expression. Therefore, the functional consequences of both polymorphisms are not immediately apparent. Both variations, however, confirmed the previously defined predisposing and protective haplotypes [20]. In this study only part of the potential promoter region was investigated. Therefore, the expression of RXRB may be influenced by polymorphisms/mutations in more distant promoter regions. Interestingly, the SNP in exon 7 might reflect differences between ANCA-negative and -positive patients. Whereas this polymorphism is associated in the ANCA-positive WG group, there is no statistical difference between the controls and ANCA-negative patient group. Although the amount of ANCA-negative patients in our study is rather small and therefore the statistics are almost underpowered, this result gives a further hint that both phenotypes may differ in their genetic background confirming recent studies, e.g. on the intracellular tyrosine phosphates (PTPN22) gene [43].

Although our initial mapping approach did not reveal an association in further regions in the HLA complex, we genotyped the previously found functionally relevant variation in the BTNL2 gene, which is associated with sarcoidosis and may present a predisposing/protective variation with low effect size [23]. Recently, several studies proposed common genetic factors for diseases characterised by autoimmune phenomena such as polymorphisms in the aforementioned PTPN22 gene or the cytotoxic T lymphocyte associated protein (CTLA4; see $[44,45])$. Considering common features of sarcoidosis and WG (e.g. autoimmune background, granulomata in the lung), variations within BTNL2 may represent risk factors for WG. Yet, in our study we did not find evidence for involvement of BTNL2 in the pathogenesis of WG, neither in the initial screen (both microsatellites flanking BTNL2 at $25 \mathrm{~kb}$ : \#1.0.2.5 and \#1.0.2.6 showing $\mathrm{p}=0.95$ and $\mathrm{p}$ $=0.63$, respectively) nor in individual genotyping with the functional rs2076530 polymorphism reported before $(\mathrm{p}=$ 0.42 , table 4 ). As a remote possibility, different variations (of low effect size) in the BTNL2 gene may have predisposing/protective nature in the pathogenesis of WG due to allelic heterogeneity.

\section{Conclusion}

Based on our largely negative association data in context with the defined WG associated region on 6p21.3, we submit that only a single region of $\sim 280 \mathrm{~kb}$ exists that is responsible for WG predisposition in the HLA complex. In case several loci of low effect size would exist, novel alternative methodological approaches are necessary to validate their association with WG on chromosome 6.

\section{Competing interests}

The author(s) declare that they have no competing interests.

\section{Authors' contributions}

PS carried out the practical laboratory work, performed primary data analyses and drafted the manuscript. PJ initiated this study, prepared the initial version of the manuscript and performed statistical analyses. EC and WLG were responsible for the clinical characterisation of the entire patient cohort. JTE encouraged the critical approach, rewrote and finalized the paper. All authors read and approved the final manuscript. 


\section{Additional material}

\section{Additional File 1 \\ Microsatellite marker panel, additional data. \\ Click here for file \\ [http://www.biomedcentral.com/content/supplementary/1471- \\ 2350-7-21-S1.pdf] \\ Additional File 2 \\ HLA-DPB1 and microsatellite \#1.0.3.7 genotyping information. \\ Click here for file \\ [http://www.biomedcentral.com/content/supplementary/1471- \\ 2350-7-21-S2.pdf]}

\section{Acknowledgements}

Many thanks to Amer Denis Akkad for technical and laboratory support.

This work was supported by a grant from the German Bundesministerium für Bildung und Forschung (Rheumanet, OI GI 9954). Supported by the DFG grant Schu I308/I-3, the Kompetenznetzwerk Rheuma and Forschungsschwerpunkt "Koerpereigene Infektabwehr", Medical University of Luebeck.

\section{References}

I. Savage CO, Cooke SP: The role of the endothelium in systemic vasculitis. J Autoimmun 1993, 6(2):237-249.

2. Watts RA, Scott DG: Vasculitis. Baillieres Clin Rheumatol 1995, 9(3):529-554.

3. Jennette JC, Falk RJ, Andrassy K, Bacon PA, Churg J, Gross WL, Hagen EC, Hoffman GS, Hunder GG, Kallenberg CG, Mccluskey RT, Sinico RA, Rees AJ, Van Es LA, Waldherr R, Wiik A: Nomenclature of systemic vasculitides. Proposal of an international consensus conference. Arthritis Rheum 1994, 37(2): 187-192.

4. Falk RJ, Jennette JC: Thoughts about the classification of small vessel vasculitis. I Nephrol 2004, I 7 Suppl 8:S3-9.

5. Watts RA, Scott DG: Epidemiology of the vasculitides. Curr Opin Rheumatol 2003, I5(I):II-I6.

6. Miterski B, Epplen JT, Gencik M: On the genetic contribution to selected multifactorial diseases with autoimmune characteristics. Cell Mol Biol (Noisy-le-grand) 2002, 48(3):33I-34l.

7. Hellmich B, Epplen JT, Gross WL: Are ANCA-associated vasculitides inherited? Clin Exp Rheumatol 2004, 22(6 Suppl 36):SI-2.

8. Ludemann J, Utecht B, Gross WL: Anti-neutrophil cytoplasm antibodies in Wegener's granulomatosis recognize an elastinolytic enzyme. J Exp Med I990, I 7 I (I):357-362.

9. Specks U: ANCA subsets: influence on disease phenotype. Cleve Clin I Med 2002, 69 Suppl 2:SII56-9.

10. van der Geld YM, Limburg PC, Kallenberg CG: Proteinase 3, Wegener's autoantigen: from gene to antigen. J Leukoc Biol 200I, 69(2): I77-190.

II. Esnault VL, Testa A, Audrain M, Roge C, Hamidou M, Barrier JH, Sesboue R, Martin JP, Lesavre P: Alpha I-antitrypsin genetic polymorphism in ANCA-positive systemic vasculitis. Kidney Int 1993, 43(6): I329-1332.

12. Gencik M, Meller S, Borgmann S, Fricke H: Proteinase 3 gene polymorphisms and Wegener's granulomatosis. Kidney Int 2000, 58(6):2473-2477.

13. Huang D, Zhou Y, Hoffman GS: Pathogenesis: immunogenetic factors. Best Pract Res Clin Rheumatol 200I, I 5(2):239-258.

14. Meller S, Jagiello P, Borgmann S, Fricke H, Epplen JT, Gencik M: Novel SNPs in the CDI 8 gene validate the association with MPO-ANCA+ vasculitis. Genes Immun 200I, 2(5):269-272.

15. Borgmann S, Endisch G, Hacker UT, Song BS, Fricke H: Proinflammatory genotype of interleukin-I and interleukin-I receptor antagonist is associated with ESRD in proteinase 3-ANCA vasculitis patients. Am J Kidney Dis 2003, 4 I(5):933-942.
16. Spencer SJ, Burns A, Gaskin G, Pusey CD, Rees AJ: HLA class II specificities in vasculitis with antibodies to neutrophil cytoplasmic antigens. Kidney Int 1992, 4 I (4): I059-1063.

17. Cotch MF, Fauci AS, Hoffman GS: HLA typing in patients with Wegener granulomatosis. Ann Intern Med 1995, I 22(8):635.

18. Hagen EC, Stegeman CA, D'Amaro J, Schreuder GM, Lems SP, Tervaert JW, de Jong GM, Hene RJ, Kallenberg CG, Daha M, van der Woude FJ: Decreased frequency of HLA-DRI3DR6 in Wegener's granulomatosis. Kidney Int 1995, 48(3):80 I-805.

19. Griffith ME, Pusey CD: HLA genes in ANCA-associated vasculitides. Exp Clin Immunogenet 1997, I 4(3): 196-205.

20. Jagiello P, Gencik M, Arning L, Wieczorek S, Kunstmann E, Csernok E, Gross WL, Epplen JT: New genomic region for Wegener's granulomatosis as revealed by an extended association screen with 202 apoptosis-related genes. Hum Genet 2004, I | 4(5):468-477.

21. Jongeneel CV, Briant L, Udalova IA, Sevin A, Nedospasov SA, Cambon-Thomsen A: Extensive genetic polymorphism in the human tumor necrosis factor region and relation to extended HLA haplotypes. Proc Natl Acad Sci U S A 199I, 88(2I):97|7-972I

22. Jeffreys AJ, Kauppi L, Neumann R: Intensely punctate meiotic recombination in the class II region of the major histocompatibility complex. Nat Genet 200I, 29(2):2I7-222.

23. Valentonyte R, Hampe J, Huse K, Rosenstiel P, Albrecht M, Stenzel A, Nagy M, Gaede KI, Franke A, Haesler R, Koch A, Lengauer T, Seegert D, Reiling N, Ehlers S, Schwinger E, Platzer M, Krawczak M, MullerQuernheim J, Schurmann M, Schreiber S: Sarcoidosis is associated with a truncating splice site mutation in BTNL2. Nat Genet 2005, 37(4):357-364.

24. Yu VC, Delsert C, Andersen B, Holloway JM, Devary OV, Naar AM, Kim SY, Boutin JM, Glass CK, Rosenfeld MG: RXR beta: a coregulator that enhances binding of retinoic acid, thyroid hormone, and vitamin $D$ receptors to their cognate response elements. Cell I99|, 67(6): |25|-1266.

25. Mathieu C, Waer M, Laureys J, Rutgeerts O, Bouillon R: Prevention of autoimmune diabetes in NOD mice by I,25 dihydroxyvitamin D3. Diabetologia 1994, 37(6):552-558.

26. Adorini L: Immunomodulatory effects of vitamin $D$ receptor ligands in autoimmune diseases. Int Immunopharmacol 2002, 2(7): $1017-1028$.

27. Adorini L: Tolerogenic dendritic cells induced by vitamin D receptor ligands enhance regulatory $T$ cells inhibiting autoimmune diabetes. Ann N Y Acad Sci 2003, 987:258-26I.

28. Adorini L, Penna G, Giarratana N, Roncari A, Amuchastegui S, Daniel KC, Uskokovic M: Dendritic cells as key targets for immunomodulation by Vitamin D receptor ligands. J Steroid Biochem Mol Biol 2004, 89-90( I-5):437-44I.

29. Leavitt RY, Fauci AS, Bloch DA, Michel BA, Hunder GG, Arend WP, Calabrese LH, Fries JF, Lie JT, Lightfoot RWJ, Masi AT, Mcshane DJ, Mills JA, Stevens MB, Wallace SL, Zvaifler NJ: The American College of Rheumatology 1990 criteria for the classification of Wegener's granulomatosis. Arthritis Rheum 1990, 33(8): I I0I- - 107

30. Santa Cruz genome browser (UCSC) [http://genome.ucsc.edu]

31. Microsatellite marker panel additional data. [http:// www.ruhr-uni-bochum.de/mhg/additional file I.pdf]

32. Storey JD: A direct approach to false discovery rates. Journal of the Royal Statistical Society, Series B 2002, 64:479-498.

33. Storey, JD; Tibshirani,R: Statistical significance for genomewide studies. Proc Natl Acad Sci U S A 2003, I 00( I 6):9440-9445.

34. Ishiguro H, Okubo $\mathrm{Y}$, Ohtsuki T, Yamakawa-Kobayashi K, Arinami T: Mutation analysis of the retinoid $X$ receptor beta, nuclearrelated receptor $I$, and peroxisome proliferator-activated receptor alpha genes in schizophrenia and alcohol dependence: possible haplotype association of nuclear-related receptor I gene to alcohol dependence. Am J Med Genet 2002, I | 4(I): I5-23

35. HLA-DPBI and microsatellite \#I.0.3.7 genotyping information. [http://www.ruhr-uni-bochum.de/mhg/additional file 2.pdf]

36. Haploview software [http://www.broad.mit.edu/personal/jcbar ret/haploview/]

37. Wieczorek S, Jagiello P, Arning L, Dahmen N, Epplen JT: Screening for candidate gene regions in narcolepsy using a microsatellite based approach and pooled DNA. J Mol Med 2004, 82(10):696-705. 
38. Katz P, Alling DW, Haynes BF, Fauci AS: Association of Wegener's granulomatosis with HLA-B8. Clin Immunol Immunopathol 1979, | 4(2):268-270.

39. Elkon KB, Sutherland DC, Rees AJ, Hughes GR, Batchelor JR: HLA antigen frequencies in systemic vasculitis: increase in HLADR2 in Wegener's granulomatosis. Arthritis Rheum 1983, 26(I): 102-105.

40. Papiha SS, Murty GE, Ad'Hia A, Mains BT, Venning M: Association of Wegener's granulomatosis with HLA antigens and other genetic markers. Ann Rheum Dis 1992, 5 I (2):246-248.

4I. Gencik M, Borgmann S, Zahn R, Albert E, Sitter T, Epplen JT, Fricke $\mathrm{H}$ : Immunogenetic risk factors for anti-neutrophil cytoplasmic antibody (ANCA)-associated systemic vasculitis. Clin Exp Immunol 1999, I I 7(2):4I2-4I7.

42. Rajsbaum R, Fici D, Fraser PA, Flores-Villanueva PO, Awdeh ZL: Polymorphism of the human retinoid $X$ receptor beta and linkage disequilibrium with HLA-DPBI. Tissue Antigens 200I, 58(I):24-29.

43. Jagiello P, Aries P, Arning L, Wagenleiter SE, Csernok E, Hellmich B, Gross WL, Epplen JT: The PTPN22 620W allele is a risk factor for Wegener's granulomatosis. Arthritis Rheum 2005, 52( I 2):4039-4043.

44. Ueda H, Howson JM, Esposito L, Heward J, Snook H, Chamberlain G Rainbow DB, Hunter KM, Smith AN, Di Genova G, Herr MH, Dahlman I, Payne F, Smyth D, Lowe C, Twells RC, Howlett S, Healy B, Nutland S, Rance HE, Everett V, Smink LJ, Lam AC, Cordell HJ, Walker NM, Bordin C, Hulme J, Motzo C, Cucca F, Hess JF, Metzker ML, Rogers J, Gregory S, Allahabadia A, Nithiyananthan R, Tuomilehto-Wolf E, Tuomilehto J, Bingley P, Gillespie KM, Undlien DE, Ronningen KS, Guja C, lonescu-Tirgoviste C, Savage DA, Maxwell AP, Carson DJ, Patterson CC, Franklyn JA, Clayton DG, Peterson LB, Wicker LS, Todd JA, Gough SC: Association of the T-cell regulatory gene CTLA4 with susceptibility to autoimmune disease. Nature 2003, 423(6939):506-5II.

45. Criswell LA, Pfeiffer KA, Lum RF, Gonzales B, Novitzke J, Kern M, Moser KL, Begovich AB, Carlton VE, Li W, Lee AT, Ortmann W, Behrens TW, Gregersen PK: Analysis of families in the multiple autoimmune disease genetics consortium (MADGC) collection: the PTPN22 620W allele associates with multiple autoimmune phenotypes. Am J Hum Genet 2005, 76(4):56I-57I.

\section{Pre-publication history}

The pre-publication history for this paper can be accessed here:

http://www.biomedcentral.com/1471-2350/7/21/prepub

\section{Publish with Bio Med Central and every scientist can read your work free of charge}

"BioMed Central will be the most significant development for disseminating the results of biomedical research in our lifetime. "

Sir Paul Nurse, Cancer Research UK

Your research papers will be:

- available free of charge to the entire biomedical community

- peer reviewed and published immediately upon acceptance

- cited in PubMed and archived on PubMed Central

- yours - you keep the copyright 